\title{
Pigmentation of the viscera and carcasses (chromatosis) in sheep in the Brazilian northeastern region
}

\author{
Pigmentação das vísceras e carcaças (cromatose) em ovinos na região Nordeste do Brasil
}

\section{Luciano da Anunciação Pimentel ${ }^{\mathrm{I}}$ João Ricardo Barbosa Araújo ${ }^{\mathrm{II}}$ Antônio Flávio Medeiros Dantas ${ }^{\mathrm{I}}$ Odaci Fernandes de Oliveira ${ }^{\mathrm{III}}$ Rosane Maria Trindade Medeiros ${ }^{\mathrm{I}}$ Franklin Riet-Correa $^{\mathrm{I}}$}

\section{- NOTE -}

\begin{abstract}
We report exogenous pigmentation in sheep grazing in native pastures in northeastern Brazil. The sheep carcasses from a farm were condemned at the slaughterhouse due to pigmentation of the carcasses and viscera. In visits to the farm, bluish-purple pigmentation of the mucosa was observed in the sheep. In two necropsied sheep, a bluish-purple pigment was observed in the skin, subcutaneous tissue, fat, muscles, cartilage, bones, serous membranes of the forestomachs, kidneys, adrenal glands, and the mucosa of the uterus, urinary bladder, urethra, vagina, trachea, bronchi, and bronchioles. Some bone surfaces, the intima of large arteries, tendons, muscle insertions, and ligaments had a yellow-brown or light brown pigment. However, the pigment was not observed upon histologic examination of tissues, suggesting that the pigmentation is caused by a plant. Two plants, Rhamnidium molle and Pereskia bahiensis, were fed to experimental sheep and rabbits, but did not cause pigmentation.
\end{abstract}

Key words: exogenous pigmentation, ruminants, carcass condemnation.

\section{RESUMO}

Descreve-se pigmentação exógena em ovinos, pastejando numa área de pastagem nativa da região nordeste do Brasil. Os ovinos de uma fazenda, destinados ao abate, tiveram as carcaças rejeitadas pelo frigorífico em virtude da pigmentação apresentada nos tecidos. Em visitas à fazenda, foi observada pigmentação azul-violeta nas mucosas de ovelhas. Em dois ovinos necropsiados, pigmento azul-violeta foi observado na pele, tecido subcutâneo, gordura, músculos, cartilagens, ossos, serosa dos pré-estômagos, rins, glândulas adrenais, mucosa do útero, bexiga urinária, uretra, vagina, traqueia, brônquios e bronquíolos. Algumas superfícies ósseas, intima de grandes artérias, tendões, inserções musculares e ligamentos tinham pigmento castanho-amarelo ou castanho claro. No entanto, o pigmento não foi observado nos tecidos após processamento para o exame histológico, o que sugere que a pigmentação é causada por uma substância exógena, provavelmente presente em uma planta consumida. Duas plantas, Rhamnidium molle e Pereskia bahiensis, foram fornecidas experimentalmente a ovinos e coelhos, mas não causaram pigmentação.

Palavras-chave: pigmentação exógena, ruminantes, condenação de carcaças.

Tissue pigmentation in domestic animals can be caused by exogenous substances, such as carotenoids, or by endogenous substances, as occurs in certain genetic diseases (JONES et al., 1997; VARASCHIN et al., 1998). In Colombia, the consumption of the plants Bunchosia pseudonitida and Bunchosia armeniaca cause pigmentation of different tissues in cattle and sheep (GÁMEZ et al., 1983a, b). In Australia, diffuse black pigment identified as lipofuscin, and observed in the liver, portal lymph nodes and, to a lesser extent, in the lungs of $3 \%$ of asymptomatic sheep slaughtered in a slaughterhouse in Brisbane was

'Hospital Veterinário, Universidade Federal de Campina Grande (UFCG), 58708-110, Patos, PB, Brasil. E-mail: franklin.riet@pq.cnpq.br. *Autor para correspondência.

"Instituto para o Desenvolvimento Social do Semiárido, Senhor do Bonfim, BA, Brasil.

'IIDepartamento de Botânica, Universidade Federal Rural do Semiárido (UFERSA), Mossoró, RN, Brasil. 
associated with the consumption of Acacia aneura (WINTER, 1961; JONES et al., 1997). Similar pigmentation was reported in sheep from the Falkland Islands (ROWLAND \& WHITLEY, 1983). In 1990, the inspection service of the United States Department of Agriculture (USDA) published a note describing the retention of eight cattle carcasses with purple pigmentation of the viscera and different tissues. However, no morphological changes were observed in tissues upon histological examination, and it was concluded that the pigmentation was most likely caused by the ingestion of a plant (STEPHENSON, 1990).

The aim of this study is to report exogenous pigmentation (chromatosis) of the carcass and viscera of sheep in the state of Bahia, Northeastern Brazil. In addition, we report the plants that were found on the farm where the condition occurred and the experimental administration of two plants suspected as being responsible for the pigmentation.

The pigmentation occurred on a farm in the municipality of Campo Formoso, located at
S10 30'33.9'" W0.40 $23^{\prime}$ '05.0', with an elevation of $831 \mathrm{~m}$. According to farmers interviewed in 2009 , young and adult sheep exhibited blue/purple (violet) pigmentation of the mucous membranes 60 to 90 days after being placed in a particular area of native vegetation (Caatinga). At slaughter, pigmentation was observed in the viscera and carcass. This pigmentation had been observed on this farm for 8 years. In 2008, 30 sheep sent to a slaughterhouse were condemned due to the pigmentation of the carcasses and viscera. Despite the commercial rejection of the carcasses, farm workers who ate the meat said that there are no changes in its taste and texture. There was no other species (goats, cattle or horses) grazing in the area where the pigmentation occurred.

During a visit to the farm, different degrees of bluish-purple pigmentation of the mucosa were observed in most of the animals examined in a flock of 60 sheep (Figure 1A). One animal that had died due to maternal dystocia and another one that was euthanized were necropsied. Both of the sheep were in good body

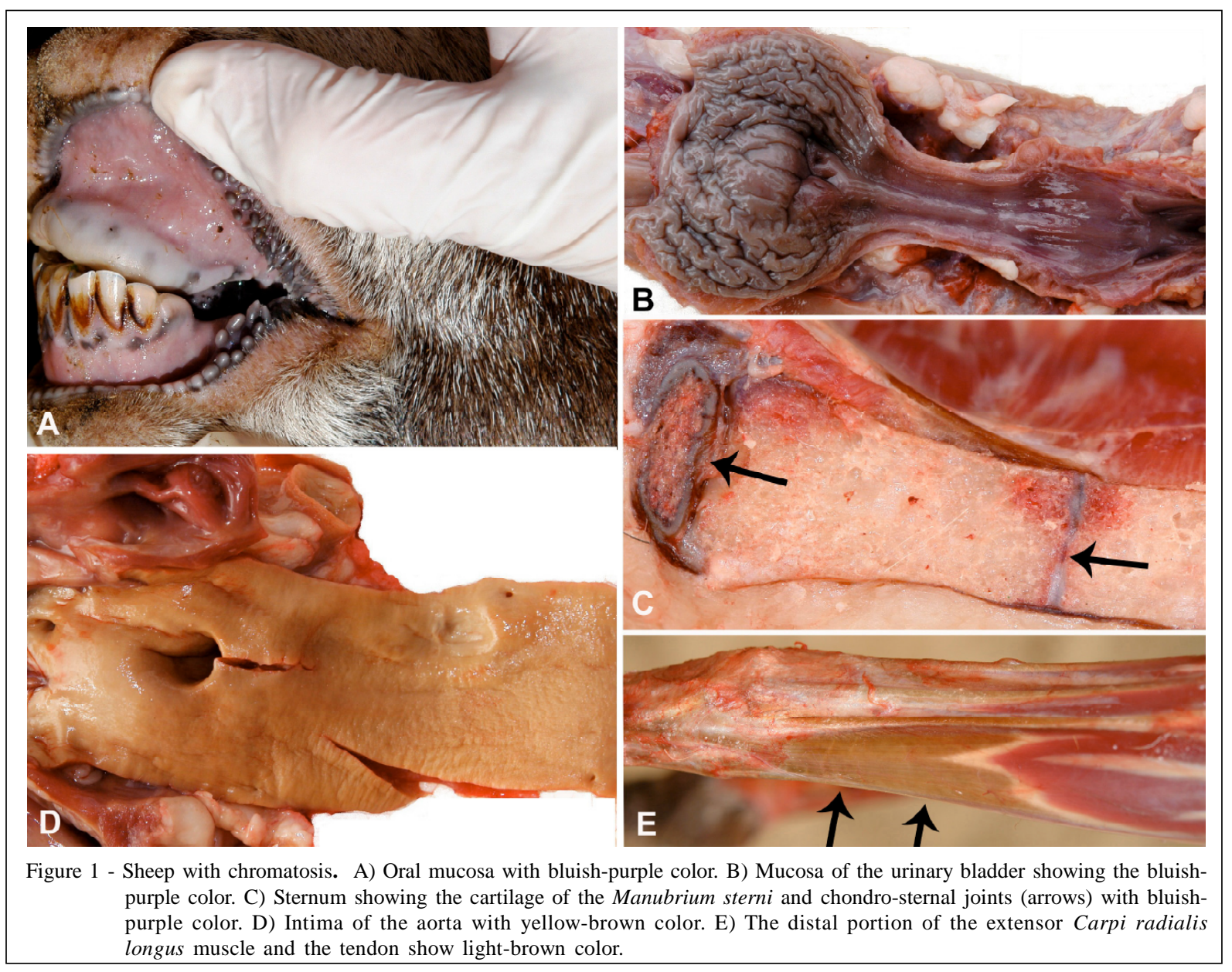

Ciência Rural, v.43, n.2, fev, 2013. 
condition, but their ocular, oral and vaginal mucous membranes were bluish-purple in color. At necropsy, the bluish-purple color was observed to varying intensities in the skin and subcutaneous tissue, muscles, surfaces of some articular cartilages and bones, particularly the inner skull and vertebrae. In the abdominal cavity, the pigment was observed in the serosa of the forestomachs, kidneys, adrenal glands and the surface of the mucous membranes of the uterus, urinary bladder, urethra and vagina (Figures 1B and 1C). In the thoracic cavity, the trachea, bronchi and bronchioles were also pigmented.

The bone surfaces of the carpal joints and other joints, fat, intima of the great arteries (Figure 1D), and some ligaments, particularly the nuchal ligament, showed yellow-brown pigmentation; in some of the joint capsules, tendons, ligaments, and muscle insertions, the pigmentation was light brown (Figure 1E). Samples of the tissues affected were fixed in $10 \%$ buffered formalin, embedded in paraffin, and stained by hematoxylin and eosin. No significant histologic lesions were observed, and the pigment did not remain in the tissues after processing.

The pastures where the cases occurred were inspected for plants that could be the cause of the disease. The native vegetation of the paddock, Caatinga, is typical of the Brazilian semiarid region: a type of forest characterized by small-sized deciduous trees and shrubs. Caatinga has herbaceous flora that is present only during the short rainy season (November-December to March-April) and that is mainly composed of species of Acanthaceae, Asteraceae, Convolvulaceae, Leguminosae and Rubiaceae. Succulent plants of the Cactaceae, Euphorbiaceae, and Bromeliaceae families and vines of the Bignoniaceae and Sapindaceae families are also common (CARDOSO et al., 2011). The main plant species found in the paddock were as follows: Rhamnidium molle Reissek; Pereskia bahiensis
Gürke; Arrojadoa rhodantha (Gürke) Britton \& Rose; Aspidosperma pyrifolium Mart.; Cnidoscolus bahianus (Ule) Pax \& K.Hoffm; Cnidoscolus quercifolius Pohl; Croton spp.; Erythroxylum sp.; Jatropha mollissima (Pohl) Baill; Jatropha ribifolia (Pohl) Baill; Melochia tomentosa L.; Neocalyptrocalyx longifolium (Mart.) Cornejo \& Iltis; Poincianella pyramidalis (Tul.) L.P. Queiroz; Spondias tuberosa Arruda; Tacinga palmadora (Britton \& Rose) N.P. Taylor \& Stuppy and Triplaris gardneriana Wedd.

The leaves of $\boldsymbol{R}$. molle, a shrub with black pigmentation in the leaves and a black fruit, and the fruits of $\boldsymbol{P}$. bahiensis, which were mentioned by farmers as the cause of the disease, were administered experimentally to 3 sheep and 2 rabbits. The doses of the plants administered are given in table 1 . The animals were slaughtered at the end of the experiment; no pigmentation was observed in the carcasses and viscera.

The occurrence of the disease in a particular area, with a high frequency in the affected flock, suggests that the pigmentation is due to plant consumption. Furthermore, the observed pigmentation is very similar to the pigmentation caused by Bunchosia spp. in Colombia (GÁMEZ et al., 1983a), which is characterized by the presence of bluish-purple pigment in asymptomatic animals that also disappears after tissue processing for histology. The disappearance of the pigment during tissue processing is probably due to its solubility in water or alcohol.

The negative results to reproduce the pigmentation with fruits of $\boldsymbol{P}$. bahiensis and leaves of $\boldsymbol{R}$. molle suggest that these two plants are not the cause of the disease. Nevertheless, $\boldsymbol{R}$. molle has a characteristic black pigment in its leaves and fruits, which suggest that this plant is probably causing the pigmentation. In this case, the failure to reproduce the disease can be due to a chemical modification of the pigment between the collection and the administration

Table 1 - Plant and doses administered to sheep and rabbits for the determination of the etiology of a chromatosis in sheep.

\begin{tabular}{|c|c|c|c|c|}
\hline Plant & Animal species & Material and form of administration & Daily dose & Administration period \\
\hline P. bahiensis & Sheep & $\begin{array}{l}\text { Fresh refrigerated fruits, cut and mixed at } 1 \% \text { with } \\
\text { concentrated food. }\end{array}$ & $20 \mathrm{~g} \mathrm{~kg}^{-1}$ & 40 days \\
\hline R. molle & Sheep & $\begin{array}{l}\text { Dry ground leaves mixed at } 40 \% \text { with concentrated } \\
\text { food. }\end{array}$ & $6 \mathrm{~g} \mathrm{~kg}^{-1}$ & 33 days \\
\hline R. molle & Sheep & Fresh leaves collected weekly and administered daily. & $6 \mathrm{~g} \mathrm{~kg}^{-1}$ & 120 days \\
\hline R. molle & Rabbit & $\begin{array}{l}\text { Fresh ground leaves mixed at } 40 \% \text { with concentrated } \\
\text { food. }\end{array}$ & $12 \mathrm{~g} \mathrm{~kg}^{-1}$ & 30 days \\
\hline R. molle & Rabbit & Similar than the other rabbit. & $24 \mathrm{~g} \mathrm{~kg}^{-1}$ & 60 days \\
\hline
\end{tabular}


of the plant. However, the possibility that some other plant is responsible for the pigmentation is not ruled out.

\section{ACKNOWLEDGMENTS}

This research was financially supported by the National Institute for Science and Technology for the Control of Poisoning Plants, grant CNPq 573534/2008-0.

\section{ETHICAL STATEMENT}

We declare to whom correspond that we assume any responsibility about any process realized during the development of the research entitled Pigmentation of the viscera and carcasses (chromatosis) in sheep. Likewise we are available to answer any questions that may be needed.

\section{REFERENCES}

CARDOSO, D.B.O.S. et al. Caatinga no contexto de uma metacomunidade: evidências da biogeografia, padrões filogenéticos e abundância de espécies em Leguminosas. In: CARVALHO C.J.B. \& ALMEIDA E.A.B. (Eds.). Biogeografia da América do Sul: padrões e processos. São Paulo: Roca, 2011. p.241-260.

GÁMEZ, J.E.T. et al. Cromatosis de los bovinos o "vaca morada" em Colombia (1 a parte). Carta Ganadera, v.20, n.6, p.25-30, 1983a.
GÁMEZ, J.E.T. et al. Cromatosis de los bovinos o "vaca morada" em Colombia (2a parte). Carta Ganadera, v.20, n.7, p.19-21 e p.65-68, 1983b.

JONES, T.C. et al. Mineral deposits and pigments. In: et al. (Eds.). Veterinary pathology. Baltimore: Lippincott Willians \& Willians, 1997. p.57-80.

ROWLAND, A.C.; WHITLEY, R.S. A preliminary report on hepatic pigmentation in Falkland Islands sheep. Veterinary Research Communications, v.6, n.1, p.235-240, 1983. Available from: <http://www.springerlink.com/content/ f2502u05kkh68288/>. Accessed: May, 8, 2011. doi: 10.1007/ BF02214918.

STEPHENSON, S.L. The purple cow's projected feast. 1990. USDA/FSIS veterinarian. Available from: <http://issuu.com/ drshinola/docs/the_purple_cow>. Accesed: May, 8, 2011.

VARASCHIN, M.S. et al. Porfiria eritropeiética congênita em bovino no Estado de Minas Gerais. Ciência Rural, v.28, n.4, p.695-698, 1998. Available from: <http://www.scielo.br/pdf/cr/ v28n4/a26v28n4.pdf>. Accessed: May, 8, 2011. doi: doi.org/ 10.1590/S0103-84781998000400026.

WINTER, H. An environmental lipofuscin pigmentation of livers. Studies on the pigmentation affecting the sheep and other animals in certain districts of Australia. Australia: University of Queensland, 1961. 66p. 